\title{
ERRATUM
}

Weihsueh A. Chiu • Frédéric Y. Bois

\section{Revisiting the population toxicokinetics of tetrachloroethylene}

Published online: 26 April 2006

(C) Springer-Verlag 2006

\section{Arch Toxicol (2006) DOI 10.1007/s00204-006-0061-9}

One of the references cited in the text for this manuscript was missing. The additional reference is:

Clewell HJ, Gentry PR, Kester JE, Andersen ME (2005) Evaluation of physiologically based pharmacokinetic models in risk assessment: an example with perchloroethylene. Crit Rev Toxicol 35:413-433

The online version of the original article can be found at http:// dx.doi.org/10.1007/s00204-006-0061-9

\footnotetext{
W. A. Chiu $(\bowtie)$

U.S. Environmental Protection Agency,

National Center for Environmental Assessment,

Washington, DC 20460, USA

E-mail: chiu.weihsueh@epa.gov

Tel.: + 1-202-5647789

Fax: + 1-202-5650079

F. Y. Bois

Institut National de l'Environnement Industriel et des Risques,

Unité de Toxicologie Expérimentale, Parc Alata, BP2,

60550 Verneuil-En-Halatte, France
} 